\title{
Perubahan Mikroklimatik Amonia pada Zona Berbeda dalam Kandang Closed House Ayam Broiler di Musim Kemarau terhadap Tampilan Karkas
}

\author{
Changes of Ammonia Microclimatic in Different Zones in Broiler Closed House during \\ Drought Season on Carcass Traits
}

\author{
A. Hidayat, T. A. Sarjana*, S. Kismiati \\ Laboratorium Produksi Ternak Unggas, Fakultas Peternakan dan Pertanian, Universitas Diponegoro \\ *Corresponding Author : teysar_adi@undip.ac.id
}

\begin{abstract}
The aim of this research was to evaluate the effect of microclimatic ammonia change in different zones in the closed house on broiler carcass traits. A total of 720 broilers Cobb strain unsexed Day Old Chick (DOC) weighing $49.25 \pm 1.13$ grams were used and maintained in a closed house with size of $60 \times 12$ meters. The applied treatments were the position of chicken placement in a closed house in a different zone such zone 1 (in the inlet), zone 2 (1/4 length of closed house from the inlet), zone 3 (1/2 length of closed house from the inlet) and zone 4 (3/4 length of closed house from inlet). The parameters observed were body weight, carcass weight, carcass percentage, non carcass weight, non carcass percentage. As supporting data for microclimate conditions including changes in microclimatics ammonia to placement in the zone observed in this research to provide an overview of the actual microclimate conditions in the closed house. The data obtained were analyzed by variance and Duncan test. The results showed that the in the zone further from the inlet there were changes in microclimatic conditions including increase in ammonia microclimatics. The further zone of broiler placement from the inlet decreased $(\mathrm{P}<0.05)$ in live weight, carcass weight and viscera weight without affecting non carcass weight, giblet weight, viscera weight, carcass percentage, non carcass percentage and viscera percentage significantly. In conclusion, the zones placement at $1 / 4$ length of closed house from the inlet increased ammonia microclimatics and decreased the broiler carcass traits.
\end{abstract}

Key words: spatial microclimatic amonia, zonation, broiler, carcass traits

\begin{abstract}
ABSTRAK
Penelitian ini bertujuan untuk mengevaluasi dampak perubahan mikroklimatik amonia pada penempatan`zona yang berbeda didalam closed house terhadap tampilan karkas ayam broiler. Penelitian menggunakan 720 ekor ayam broiler strain cobb unsexed dengan bobot Day Old Chick (DOC) 49,25 \pm 1,13 gram yang dipelihara di kandang closed house berukuran 60 x 12 meter. Perlakuan yang diterapkan yaitu posisi penempatan ayam di dalam kandang closed house pada zona berbeda yaitu zona 1 (tepat pada inlet), zona 2 ( $1 / 4$ panjang closed house dari inlet), zona 3 ( $1 / 2$ panjang closed house dari inlet) dan zona 4 ( $3 / 4$ panjang closed house dari inlet). Parameter yang diamati terdiri dari bobot hidup, bobot karkas, persentase karkas, bobot non karkas dan persentase non karkas. Sebagai data pendukung kondisi mikroklimat termasuk perubahan mikroklimatik amonia akibat penempatan pada zona diamati pada penelitian ini untuk memberikan gambaran kondisi aktual mikroklimat didalam closed house. Data yang didapatkan dianalisis ragam dan uji Duncan. Penelitian menunjukkan bahwa pada zona yang semakin jauh dari inlet terdapat perubahan kondisi mikroklimatik termasuk peningkatan mikroklimatik amonia. Penempatan ayam saat menjauhi inlet nyata $(\mathrm{P} \leq 0,05)$ menurunkan bobot hidup, bobot karkas dan bobot viscera namun tidak mempengaruhi bobot non karkas, bobot giblet, bobot viscera, persentase karkas, persentase non karkas dan persentase viscera secara nyata. Disimpulkan bahwa penempatan zona pada jarak $1 / 4$ panjang kandang dari inlet diikuti dengan peningkatan mikroklimatik amonia sudah mulai menurunkan tampilan karkas broiler.
\end{abstract}

Kata kunci :spasial mikroklimatik amonia, zonasi, broiler, tampilan karkas

\section{PENDAHULUAN}

Musim kemarau di Kota Semarang memiliki karakteristik suhu dan kelembaban yang tinggi meskipun kelembabannya tidak setinggi pada musim penghujan. Suhu lingkungan pada musim kemarau menurut data Badan Meteorologi Klimatologi dan Geofisika (BMKG) rata-rata sebesar 25$33^{\circ} \mathrm{C}$. Kondisi makroklimat memiliki 
kontribusi yang besar dalam memberikan udara yang masuk ke dalam kandang sehingga berpeluang terhadap perubahan mikroklimat dalam kandang. Peningkatan suhu dan radiasi matahari kearah optimasi suhu perkembangan mikroba akan meningkatkan volatilisasi amonia. Aktivitas mikroba yang lebih besar berdampak pada peluang volatilisasi amonia yang lebih besar apabila berada dalam kondisi suhu yang hangat, kelembaban yang normal atau cenderung lebih tinggi (Sarjana et al., 2017., Knitova et al., 2010).

Mikroklimat adalah suatu kondisi lingkungan yang ada dalam kandang seperti suhu udara, kelembaban udara dan kecepatan angin (Saputra et al., 2015). Pembagian zona dalam kandang yang secara teknis dilakukan dalam bentuk pen digunakan untuk mengatur persebaran ayam dalam kandang dan meratakan konsumsi pakan dan minum. Kondisi tersebut berdampak pada potensi volatilisasi pada zona tersebut sehingga berdampak pada perubahan mikroklimatik amonia. Perubahan mikroklimatik amonia merupakan perubahan produk fermentasi oleh mikroba dari kotoran unggas yang tervolatilisasi dan menjadi komponen penyusun udara di dalam kandang yang berperan negatif dalam kandang karena bersifat polutan. Zona yang dekat dengan cooling pada memiliki suhu yang lebih rendah dibandingkan dengan zona yang dekat exhaust fan sehingga suhu, kelembaban dan mikroklimatik amonia berbeda setiap zonanya (Renata et al., 2018).

Peningkatan mikroklimatik amonia menyebakan terganggunya paru - paru ayam karena adanya iritasi pada parabronkus. Iritasi pada bagian parabronkus menyebabkan uptake oksigen rendah diikuti dengan stres oksidatif (Wideman et al., 2013). Terganggunya paru - paru ayam dapat juga berdampak pada inefisiensi heatloss sehingga mengakibatkan gangguan pengeluaran panas dan meningkatkan suhu tubuh (Charles dan Payne, 1966). Peningkatan suhu tubuh pada ternak dan stress oksidatif akan diikuti dengan penurunan konsumsi pakan. Pada penelitian
Yahav (2004) peningkatan emisi amonia dari 16 ke 23 ppm menyebabkan penurunan konsumsi pakan sebesar $10,16 \%$. Akibat dari konsumsi pakan yang berkurang menyebabkan penurunan bobot hidup, bobot karkas dan non karkas. Penelitian Miles et al. (2004) menunjukkan bahwa peningkatan emisi amonia dari 0 ke 25 ppm menyebabkan turunnya bobot hidup ayam sebesar $2 \%$.

Penelitian ini bertujuan untuk mengamati dampak perubahan mikroklimatik amonia pada zona yang berbeda dalam kandang closed house di musim kemarau terhadap tampilan karkas pada musim kemarau. Manfaat dari penelitian ini yaitu dapat memberikan informasi tentang perubahan mikroklimatik amonia pada zona yang berbeda dalam kandang closed house di musim kemarau terhadap terhadap tampilan karkas pada musim kemarau. Hipotesis pada penelitian ini yaitu peningkatan mikroklimatik amonia pada zona yang berbeda dalam kandang closed house di musim kemarau diduga menurunkan tampilan karkas.

\section{MATERI DAN METODE}

Penelitian ini menggunakan 720 ekor DOC (Day Old Chick) strain Cobb unsex dengan bobot badan awal 49,25 $\pm 1,13$ gram. Ayam dipelihara di kandang closed house dengan panjang 60 meter dan lebar 12 meter dan kapasitas 11000 ekor. Penelitian ini menggunakan rancangan acak kelompok dengan 4 perlakuan dan 6 kelompok. Perlakuan yang digunakan yaitu posisi penempatan ayam di dalam kandang closed house pada zona berbeda yaitu pada (Zona 1: tepat samping inlet sebesar 1,42 ppm), (Zona 2 : 1/4 panjang kandang sebesar 2,67 ppm), (Zona $3: 1 / 2$ panjang kandang sebesar 4,28 ppm) dan (zona 4: $3 / 4$ panjang kandang sebesar 6,36 ppm). Masing - masing unit percobaan diisi sebanyak 30 ekor ayam. Pakan yang digunakan yaitu pakan komersial S10 dari umur 1-14 hari, S11 dari umur 1527 hari dan S12 dari umur 28-35 hari (Tabel $1)$. 
Tabel 1. Kandungan nutrisi ransum yang digunakan

\begin{tabular}{|c|c|c|c|}
\hline \multirow{2}{*}{ Zat makanan } & \multicolumn{3}{|c|}{ Kandungan } \\
\hline & $\mathrm{S} 10$ & S11 & S12 \\
\hline $\mathrm{EM}(\mathrm{kkal} / \mathrm{kg}) * *$ & 3155 & 3122 & 3072 \\
\hline Serat kasar $(\%)^{*}$ & 4,94 & 6,32 & 5,57 \\
\hline Protein kasar $(\%) *$ & 20,22 & 19,31 & 18,27 \\
\hline Kadar air $(\%)^{*}$ & 10,59 & 10,79 & 12,2 \\
\hline Lemak kasar $(\%)^{*}$ & 5,56 & 6,04 & 5,60 \\
\hline $\operatorname{Abu}(\%)^{*}$ & 5,44 & 5,39 & 5,58 \\
\hline $\mathrm{Ca}(\%)^{*}$ & 1,08 & 1,16 & 0,91 \\
\hline $\mathrm{P}(\%)^{*}$ & 0,85 & 0,88 & 0,50 \\
\hline $\begin{array}{ll}* & : \text { Hasi } \\
& \text { Dip } \\
* * & : \text { Berc }\end{array}$ & orium & akultas & $\begin{array}{l}\text { nian Universitas } \\
\text { o et al. (2017) }\end{array}$ \\
\hline
\end{tabular}

Paramater yang diamati yaitu tampilan karkas termasuk bobot hidup, bobot karkas dan persentase karkas dan komponen non karkas termasuk bobot non karkas, persentase non karkas, bobot viscera, persentase viscera, bobot giblet dan persentase giblet. Persentase karkas, persentase non karkas, persentase viscera, persentase giblet dan persentase lemak abdominal dinyatakan dalam \% dari bobot hidup. Data yang didapatkan selanjutnya dianalisis ragam dan dilanjtkan dengan uji Duncan pada taraf 5\% apabila menunjukkan pengaruh yang signifikan.

Tabel 2. Rataan kondisi makroklimat, mikroklimat dan mikroklimatik amonia kandang pada minggu terakhir

\begin{tabular}{|c|c|c|c|c|}
\hline \multicolumn{2}{|c|}{ Makroklimat } & \multicolumn{3}{|c|}{ Nilai } \\
\hline Suhu $\left({ }^{\circ} \mathrm{C}\right)$ & & & 29,62 & \\
\hline Kelembaban $(\%)$ & & & 64,83 & \\
\hline Kecepatan angin $(\mathrm{m} / \mathrm{s})$ & & & 2,10 & \\
\hline Curah hujan* $(\mathrm{mm})$ & & & $50-100$ & \\
\hline Mikroklimat & Zona 1 & Zona 2 & Zona 3 & Zona 4 \\
\hline Mikroklimatik amonia (ppm) & 1,42 & 2,67 & 4,28 & 6,36 \\
\hline Suhu $\left({ }^{\circ} \mathrm{C}\right)$ & 26,33 & 26,87 & 27,56 & 28,50 \\
\hline Kelembaban $(\%)$ & 78,28 & 77,39 & 75,18 & 74,35 \\
\hline Kecepatan angin $(\mathrm{m} / \mathrm{s})$ & 1,73 & 1,36 & 1,08 & 0,72 \\
\hline Heat stress index*** & 157,68 & 157,76 & 156,79 & 156,83 \\
\hline
\end{tabular}

Keterangan : * Data diambil dari Badan Meteorologi, Klimatologi, dan Geofisika bulan Juni - Juli 2017di Kota Semarang (BMKG, 2017) $* *=50-100 \mathrm{~mm}=$ Curah hujan kategori rendah $\left.* * *=\left(\left(9 / 5 \mathrm{x}^{\circ} \mathrm{C}\right)+\%\right)\right)+32$ (Aviagen, 2010)

Gambaran kondisi faktor - faktor yang diduga berpengaruh terhadap perubahan mikroklimatik amonia dan gambaran kondisi tingkat stress ayam yang diukur berdasarkan nilai heat stress index disajikan pada Tabel 2 diatas.

\section{HASIL DAN PEMBAHASAN}

Hasil analisis ragam pada Tabel 3 menunjukkan bahwa zona yang semakin jauh dari inlet mengakibatkan penurunan bobot hidup, bobot karkas dan bobot viscera secara nyata $(\mathrm{P} \leq 0,05)$ namun tidak dengan bobot non karkas, bobot giblet, bobot lemak abdomen, persentase karkas, persentase non karkas, persentase viscera, persentase giblet dan persentase lemak abdomen. Sebagaimana disajikan pada Tabel 2 semakin jauh zona dari inlet terdapat peningkatan kondisi mikroklimatik amonia sementara nilai hsi relatif tetap meskipun terdapat perubahan komponen suhu dan kelembaban. 
Tabel 3. Tampilan karkas

\begin{tabular}{|c|c|c|c|c|c|c|}
\hline \multirow{2}{*}{ Parameter } & \multicolumn{6}{|c|}{ Tampilan Karkas } \\
\hline & Zona 1 & Zona 2 & Zona 3 & Zona 4 & $\mathrm{P}$ & SE \\
\hline Bobot hidup & $2226,67^{\mathrm{a}}$ & $1928,33^{b}$ & $1845,00^{\mathrm{bc}}$ & $1760,83^{\mathrm{c}}$ & 0,00 & 0,41 \\
\hline Bobot karkas & $1659.17^{\mathrm{a}}$ & $1435.17^{b}$ & $1322.83^{\mathrm{c}}$ & $1281.83^{c}$ & 0,00 & 0,44 \\
\hline Persentase karkas & 74,52 & 74,61 & 71,72 & 72,75 & 0,47 & 0,01 \\
\hline Bobot non karkas & 567.50 & 493.17 & 522.17 & 479.00 & 0,18 & 0.61 \\
\hline Persentase non karkas & 25.48 & 25.39 & 28.29 & 27.25 & 0,43 & 0.02 \\
\hline Bobot viscera & $274^{\mathrm{a}}$ & $234.17^{b}$ & $215.50^{b}$ & $201.17^{b}$ & 0,04 & 0.02 \\
\hline Persentase viscera & 12,33 & 12,09 & 11,68 & 11,42 & 0,76 & 0.09 \\
\hline Bobot giblet & 94.00 & 86.67 & 73.83 & 79.17 & 0,44 & 0.03 \\
\hline Persentase giblet & 3.68 & 4.50 & 4.00 & 4.00 & 0,79 & 0.15 \\
\hline Bobot lemak Abdominal & 15,83 & 16,00 & 20,00 & 17,33 & 0,19 & 0,06 \\
\hline Persentase lemak Abdominal & 0.71 & 0,83 & 1,09 & 0,98 & 0,09 & 0,06 \\
\hline
\end{tabular}

Keterangan $\quad$ : Superskrip yang berbeda pada baris yang sama menunjukkan perbedaan yang nyata $(\mathrm{P}<0,05)$

Perbedaan musim menjadi salah satu faktor yang mempengaruhi perubahan mikroklimatik amonia. Pada penelitian Renata et al. (2018) dalam kandang yang sama di musim penghujan, rata-rata mikroklimatik amonia sebesar 4,02 ppm. Hasil tersebut lebih besar 8,46\% dibandingkan pada penelitian ini sebesar 3,68 ppm. Perbedaan ini terjadi diduga dikarenakan pada musim kemarau meskipun suhu lebih tinggi tapi kecepatan anginnya lebih tinggi dibandingkan penghujan.

Adanya manajemen yang berbeda pada setiap musim mempengaruhi perubahan mikroklimatik amonia. Peningkatan mikroklimat amonia yang berbeda dapat dikarenakan adanya kecepatan angin. Kecepatan angin yang menurun merupakan penyebab peningkatan mikroklimatik amonia pada zona yang jauh dari inlet. Mikroklimatik amonia meningkat sebesar 4 kali lipat sedangkan heat stress index menurun sebesar $0,54 \%$ pada zona yang jauh dari inlet. Hal ini menunjukkan bahwa pengaruh peningkatan mikroklimatik amonia jauh lebih besar terhadap tampilan karkas yang lebih rendah dibandingkan perubahan suhu dan kelembaban yang direprentasikan dalam heat stress index.

\section{Bobot Hidup}

Tabel 3. menunjukkan bahwa bobot hidup pada penelitian ini berkisar 1760,33 2226,67 g. Nilai ini lebih tinggi dari kisaran normal menurut pendapat Anggitasari et al. (2016) yaitu $1,2-1,9 \mathrm{~kg} / \mathrm{ekor}$ dan pendapat Fijana et al. (2012) yaitu 1,6 - 1,8 kg/ekor.

Pada zona yang jauh dari inlet peningkatan mikroklimatik amonia dalam kandang closed house nyata $(\mathrm{P} \leq 0,05)$ menurunkan bobot hidup. Hal ini diduga peningkatan mikroklimatik amonia berkontribusi terhadap peluang terjadinya iritasi parabronkus sehingga mengakibatkan ayam terkena inefisiensi heat loss. Kondisi ini mengakibatkan konsumsi pakan ayam menurun yang berdampak pada penurunan bobot hidup. Hal ini sesuai dengan pendapat Charles dan Payne (1966); Yahav (2004); Tamzil (2014) yang menyatakan bahwa amonia yang semakin tinggi akan mengganggu pelepasan panas unggas sehingga berdampak pada penurunan konsumsi pakan dan peningkatan konsumsi minum.

Inefisiensi heat loss diduga menyebabkan terjadinya heat stress dan menyebabkan ternak terkena stress oksidatif. Stress oksidatif menyebabkan penurunan konsumsi pakan dan inefisiensi nutrient yang berdampak penurunan bobot hidup. Hal ini sesuai dengan pendapat Kusnadi (2008) dan Salami et al. (2015) yang menyatakan bahwa stress oksidatif dapat berdampak pada penurunan konsumsi pakan, pertumbuhan dan inefisiensi nutrien.

Potensi kerusakan pada parabronkus akibat peningkatan mikroklimatik amonia 
pada zona yang jauh dari inlet diduga menyebabkan terjadinya penurunan daya ikat oksigen sehingga berdampak pada penurunan laju metabolisme. Hal ini sesuai dengan pendapat Sahan et al. (2006) yang menyatakan bahwa penurunan daya ikat oksigen dapat menyebabkan hipoksemia sehingga mempengaruhi metabolisme. Menurut Scheele (1997) menyatakan bahwa konsumsi oksigen mempengaruhi jumlah energi bebas yang digunakan untuk mengontrol metabolisme. Hal ini menunjukkan bahwa semakin rendah daya ikat oksigen maka akan semakin rendah jumlah energi yang tersedia sehingga berdampak pada bobot hidup yang lebih rendah.

\section{Bobot dan Persentase Karkas}

Hasil pada Tabel 3. menunjukkan bahwa pada zona yang jauh dari inlet peningkatan mikroklimatik amonia dalam kandang closed house nyata $(\mathrm{P} \leq 0,05)$ menurunkan bobot karkas namun tidak berpengaruh dengan persentase karkas. Bobot karkas pada penelitian ini sebesar 1281,83 - 1659,17 gram dengan persentase 71,72 - 74,61\%. Persentase karkas pada penelitian ini masih berada dalam kisaran normal sesuai dengan pendapat Subekti et al. (2012) dan Saputra (2015) yaitu $65-75 \%$. Sebagaimana dijelaskan diatas, peningkatan mikroklimatik amonia berpotensi menurunkan ketersediaan oksigen, konsumsi pakan dan laju metabolisme, sehingga berdampak pada penurunan energi metabolisme. Hal ini sesuai dengan pendapat Parakkasi (1983) dan Wahju (2004) yang menyatakan bahwa energi basal metabolisme salah satunya dibutuhkan untuk sintesis komponen - komponen tubuh dan pertumbuhan jaringan tubuh. Menurut Tarmudji (2005) oksigen dibutuhkan oleh protein untuk proses metabolismenya. Ketersediaan oksigen yang berkurang pada penempatan yang jauh dari inlet maka diduga menyebabkan turunnya metabolisme protein yang berdampak pada penurunan bobot karkas.
Sebagaimana yang telah dijelaskan diatas sebelumnya potensi peningkatan Inefisiensi heatloss akibat peningkatan mikroklimatik amonia pada zona yang jauh dari inlet menyebabkan cekaman panas pada ayam yang berpotensi menurunankan hormone $\mathrm{T}_{3}$ yang berperan dalam mengatur termoregulasi. Hal ini sesuai dengan hasil penelitian yang disampaikan kusnadi dan Rahim (2009) yang menyatakan bahwa suhu tubuh ternak yang meningkat akan menurunkan hormon $\mathrm{T}_{3}$ dalam tubuh yang berdampak pada penurunan konsumsi pakan dan laju metabolisme tubuh. Menurut Kusnadi (2006) Hormon $T_{3}$ dapat berdampak pada sintesis protein. Penurunan konsumsi pakan, laju metabolisme tubuh dan sintesis protein akan berdampak pada bobot karkas yang lebih rendah.

\section{Bobot dan Persentase Non Karkas}

Berdasarkan Tabel 3 diatas menunjukkan bahwa pada zona yang jauh dari inlet peningkatan mikroklimatik amonia dalam kandang closed house tidak memberikan pengaruh nyata $(\mathrm{P} \geq 0,05)$ terhadap persentase non karkas. Persentase non karkas pada penelitian ini sebesar 25,39 $28,29 \%$. Hasil ini masih dalam batas normal dikarenakan persentase karkas masih dalam batas normal juga. Viscera merupakan bagian non karkas. Meskipun data pada Tabel 3 tidak menunjukan perubahan pada bobot non karkas, namun sudah terjadi penurunan pada bobot viscera pada zona yang jauh dari inlet. Hal ini disebabkan oleh penurunan konsumsi pakan sebagaimana yang telah dibahas diatas karena peningkatan mikroklimatik amonia. Hal ini sesuai dengan pendapat Murwani (2010) dan Amrullah (2004) yang menyatakan bahwa proses perkembangan saluran pencernaan dipengaruhi oleh konsumsi pakan, jenis pakan atau makanan yang diberikan. Jika konsumsi pakan menurun maka akan berdampak pada penurunan bobot saluran pencernaan.

Penurunan konsumsi pakan akibat terjadinya termoregulasi akan berdampak pada penurunan konsumsi energi. Pada penelitian ini bobot hidup dan bobot karkas 
lebih rendah pada zona yang jauh dari inlet sementara bobot lemak abdominalnya tidak berubah. Hal ini menunjukkan bahwa dominasi penurunan konsumsi pakan akan lebih mempengaruhi protein dibandingkan lemak. Hal ini sesuai dengan hasil penelitian Renata et al. (2018) bahwa kadar protein kasar dalam daging lebih tinggi dibandingkan kadar lemak kasar. Menurut Moreng dan Avens (1985) konsumsi pakan pada ayam lebih banyak dirubah menjadi protein karkas dibandingkan lemak.

\section{KESIMPULAN}

Penempatan zona pada jarak $1 / 4$ panjang kandang dari inlet diikuti dengan peningkatan mikroklimatik amonia sudah mulai menurunkan tampilan karkas dengan zona 4 diperoleh bobot hidup dan bobot karkas yang paling rendah. Sebaiknya

dilakukan pemasangan deflektor dalam kandang agar kecepatan angin dalam kandang merata sehingga dapat mengurangi emisi amonia terutama pada zona yang jauh dari inlet.

\section{DAFTAR PUSTAKA}

Amrullah, I. K. 2004. Nutrisi Ayam Broiler. Lembaga Satu Gunungbudi. Bogor.

Anggitasari, S., O. Sjofjan dan I. H. Djunaidi. 2016. Pengaruh beberapa jenis pakan komersial terhadap kinerja produksi kuantitatif dan kualitatif ayam pedaging. Buletin Peternakan. 40 (3) : 187-196.

Aviagen. 2010. Ross Enviromental Management in the Broiler House http://en.aviagen.com/assets/Tech_Ce nter/Ross_Broiler/Ross_Environment al_Management_in_the Broiler_Hou se.pdf. 10 November 2018.

Badan Meteorologi, Klimatologi, dan Geofisika. 2017. Informasi Curah Hujan Bulanan. https://www.bmkg.go.id/iklim/informasihujan-bulanan.bmkg? $\mathrm{p}=$ analisis-curahhujan-dan-sifat-hujan-bulan-juni2017\&lang=ID. 11 November 2018.
Charles, D. R dan C. G. Payne. 1966. The influence of graded levels of atmospheric ammonia on chickens. British Poultry Science. 7 (3) : 177-187.

Fijana, M. F., E. Suprijatna dan U. Atmomarsono. 2012. Pengaruh proporsi pemberian pakan pada siang malam hari dan pencahayaan pada malam hari terhadap produksi karkas ayam broiler. Animal Agriculture Journal. 1 (1) : 697710.

Knitova, M., S. Mihina., J. Broucek., I. Karandusovska dan J. Macuhova. 2010. Ammonia Emissions from broiler housing facility : Influence Of Litter Properties and Ventilation. Prosiding Cigr XVIIth World Congress - Quebec City, Canada. 13-17 June 2010. 1-10.

Kusnadi, E. 2006. Suplementasi vitamin C sebagai penangkal cekaman panas pada ayam broiler. JITV 11 (4) : 249-253.

Kusnadi, E. 2008. Peredaman cekaman oksidatif ayam broiler yang diberi antanan (Centella asiatica) dan vitamin $\mathrm{C}$ serta kaitannya dalam menurunkan kadar lemak karkas dan kolesterol plasma. JITV. 13 (1) : 1-7.

Kusnadi, E dan F. Rahim. 2009. Performa dan kandungan triiodotironin plasma ayam broiler akibat pengaruh cekaman panas di daerah tropis. Media Peternakan. 32 (3): 155-162.

Miles, D. M., S. L. Branton dan B. D. Lott. 2004. Atmospheric ammonia is detrimental to the performance of modern commercial broilers. Poultry Science. 83 : 1650-1654.

Moreng, R. E dan J. S. Avens. 1985. Poultry science \& production. Reston Publicing Company, Inc. Virginia.

Murwani, R. 2010. Broiler Modern. Cetakan Pertama. Widya Karya. Semarang.

Parakkasi, A. 1983. Ilmu Gizi dan Makanan Ternak Monogastrik. Bandung: Angkasa.

Renata, T. A. Sarjana dan S. Kismiati. 2018. Pengaruh zonasi dalam kandang closed 
house terhadap kadar amonia dan dampaknya pada kualitas daging broiler di musim penghujan. J. Ilmu-Ilmu Peternakan. 28 (3) : 183-191.

Sahan, U., A. Ipek., O. Altan dan B. Y. Dikmen. 2006. Effects of oxygen supplementation during the last stage of incubation on broiler performance, ascites susceptibility and some physiological traits. Anim. Res. $55: 145-152$.

Salami, S. A., M. A. Majoka, S. Saha., A. Garber dan J. F. Gabarrou. 2015. Efficacy of dietsary antioxidants on broiler oxidative stress, performance and meat quality: science and market. Avian Biology Research. 8 (2) : 65-78.

Saputra, H. T., N. Khaira dan S. Dian. 2015. Pengaruh penggunaan berbagai jenis litter terhadap bobot hidup, karkas, giblet, dan lemak abdominal broiler fase finisher di closed house. Jurnal Ilmiah Peternakan Terpadu. 3 (1) : 38-44.

Sarjana, T. A., L. D. Mahfudz, M. Ramadhan, Sugiharto, F. Wahyono dan S. Sumarsih. 2017. Emisi amonia dan kondisi litter pada kandang ayam broiler system terbuka yang mendapatkan additive berbeda dan kombinasinya dalam ransum. Prosiding Seminar Nasional Pengembangan Peternakan Berkelanjutan 9. Universitas Padjajaran, 15 November 2017. Sumedang, Indonesia. 580-586

Scheele, C. W. 1997. Pathological changes in metabolism of poultry related to increasing production levels. Vet. Q. 19:127-130.

Subekti, K., H. Abbas dan K. A. Zura. 2012. Kualitas karkas (berat karkas, persentase karkas dan lemak abdomen) ayam broiler yang diberi kombinasi CPO (Crude Palm Oil) dan vitamin C (Ascorbic Acid) dalam ransum sebagi anti stress. J. Peternakan Indonesia. 14 (3) : 447-453.

Sugiharto, S., T. Yudiarti and I. Isroli. 2017. Effects of feeding cassava pulp fermented with Acremonium charticola on growth performance, nutrient digestibility and meat quality of broiler chicks. Journal of Animal Science, South African. 47 (2) : 130-138.

Tamzil, M. H. 2014. Stres panas pada unggas : metabolisme, akibat dan upaya penanggulangannya. Wartazoa. 24 (2) : $57-66$.

Tarmudji. 2005. Asites pada ayam pedaging. Wartazoa. 15 (1):38- 48.

Wahju. 2004. Ilmu Nutrisi Unggas. Universitas Gajah Mada Press. Yogyakarta.

Wideman, R. F, D. D Rhoads, G. F Erf dan N. B Anthony. 2013. Pulmonary arterial hypertension (Ascites syndrome) in broilers: A review. Poultry Science 92 : 64-83.

Yahav, S. 2004. Ammonia affects performance and thermoregulation of male broiler chickens. Animal Research. 53 : 289293. 